\title{
Roland Schmidtbleicher
}

\section{Die Anleihegläubigermehrheit}

Eine institutionenökonomische, rechtsvergleichende und dogmatische Untersuchung

[The Bondholder Multitude. A Study from the Perspective of Institutional Economics, Comparative Law and Dogmatics.]

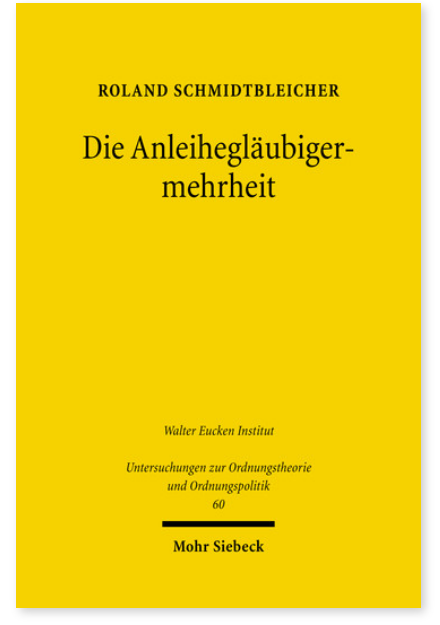

2010. XXIX, 443 pages. UOrd 60

ISBN 978-3-16-150643-7

sewn paper $79,00 €$

ISBN 978-3-16-151485-2

eBook PDF 79,00€
Published in German.

Bondholders are faced with a collective action problem in respect to amending indenture and covenants as well as monitoring the issuer. The author focuses on how this problem can or should be regulated. His approach is to analyze the problem and possible solutions, apart from the existing legislation, by using the instruments of the new institutional economics. His analysis results in a basis for comparison of the special legislation in Germany, Switzerland, France, Austria, Great Britain and the USA. In conclusion, the author shows how a legal statute which addresses the collective action problems of bondholders can be derived from the German general law of obligations.

Roland Schmidtbleicher Geboren 1979; Studium der Rechtswissenschaft mit wirtschaftswissenschaftlicher Zusatzausbildung in Bayreuth und Frankfurt am Main; wissenschaftlicher Mitarbeiter am Institute for Law and Finance der Goethe-Universität in Frankfurt; seit 2009 Rechtsreferendar in Frankfurt und Speyer; 2010 Promotion.

\section{Order now:}

https://www.mohrsiebeck.com/en/book/die-anleiheglaeubigermehrheit-9783161506437?no_cache=1

order@mohrsiebeck.com

Phone: +49 (0)7071-923-17

Fax: $+49(0) 7071-51104$ 